PEDULI: Jurnal Ilmiah Pengabdian Pada Masyarakat, 2021, Vol.5, No.2

ISSN: 25974653. EISSN:25974688

http://peduli.wisnuwardhana.ac.id/index.php/peduli/index

\title{
SOCIALIZATION OF JOINT BUMDES TAXATION TO ENCOURAGE TAX AWARENESS AND UNDERSTANDING
}

\author{
Asih Machfuzhoh ${ }^{1}$, Intan Puspanita ${ }^{2}$, Refi Pratiwi ${ }^{3}$ \\ ${ }^{1,2,3}$ Universitas Sultan Ageng Tirtayasa \\ ${ }^{1}$ asih.machfuzhoh@untirta.ac.id, 2intan.puspanita@untirta.ac.id, ${ }^{3}$ refi.pratiwi@untirta.ac.id
}

\begin{abstract}
Abstrack: Bumdes have many roles in assisting village development, so the government encourages the formation of Bumdesa in a village. UU No. 6/2014 on Villages (UUDesa). 43/2014 explains that the business entity was formed to prepare village financial management. It also explains that although it is not mandatory and coercive, the establishment of BUmdes is an opportunity for every village. In providing facilities for village financial management, it is necessary to establish a Bumdes. If a Bumdes is not formed, the village will experience difficulties in managing village funds. Bumdes has a very important role, namely as a sector of new industrial drivers and participates in accelerating the people's economic improvement. The management of village funds, whether obtained from the central government, regional governments or from village governments with the aim that these funds are used more for the economy and basic needs services, is the reason for the need for Bumdes. Many do not understand how the tax treatment of Bumdes will be. An entity in the form of a business entity formed from separated village assets as is the case with BUMN and BUMD is the definition of Bumdes. We do this service to BUM Desma Mina Agro, Pandegelang, Banten. The implementation is by conducting socialization and assistance related to understanding taxation. With this dedication, this BUM Desa Bersama understands and understands that there are tax obligations that must be fulfilled as obligations to the state.
\end{abstract}

Keywords: Village Owned Enterprises, Understanding, Tax Awareness.

\section{INTRODUCTION}

The current development paradigm is more focused on "Developing Villages" while previously, village development focused on "Building Villages". Law Number 6 of 2014 concerning this Design makes the village to initiate itself by creating a new spirit by creating the spirit of "village building". The village is used as the starting point for the success of the national development of a country. The village was initially only an object of development, but now the village is the subject of the development of the village itself. Because this makes the village community also have the opportunity to build their village independently in accordance with the advantages of the village. The ability of the village to explore the potential of local wisdom and the spirit of mutual cooperation from its citizens cannot be separated from strengthening the village itself.

Law Number 6 of 2014 is the basis for the issuance of Regulation of the Minister of Villages for Development of Disadvantaged Regions and Transmigration Number 4 of 2015 concerning the Establishment, Management, Management and Dissolution of VillageOwned Business Entities, which aims to motivate villages in managing the resources owned by their villages, including the economic development of their communities. Village Owned Enterprises (BUMDes) were formed as a way of managing the economy of rural communities. BUMDes was also formed with the hope of increasing the welfare of the local 
village community, both increasing the economy and increasing original income from the village, while also increasing efforts to process the potential possessed by the village (natural resources and human resources) in accordance with the needs of the village. the village community and serve as the basis for equity and village economic growth (Agunggunanto, 2016). BUMDes is a business entity originating from village assets which is separated to manage assets, services, and other businesses for the greatest welfare of the village community (Ihsan, 2018).

BUMDes has a very large role that can help from the development of tourist villages so that the government encourages a village to form BUMDes, especially for villages that have the potential of the tourism sector. Law No. 6/2014 concerning Villages (UU Desa) states that Bumdesa was established to manage the finances of a village in accordance with applicable regulations. Villages are given the same opportunity to establish BUMDes, this is stated in Article 87 of the Village Law and Article 132 of PP No. 43/2014 which explains the establishment of BUMDes although it is not something that is mandatory or coercive. The existence of BUMDes is undeniably bringing changes in the economic and social fields (Anggraeni, 2016).

Entrepreneurship from a village can be accommodated in a Village Owned Enterprise (BUMDes) which can be developed by the local government and village communities (Prabowo, 2014). The establishment of BUMDes is based on the needs and potential of the village, as an effort to improve community welfare (Agus, et al. 2018). Facilitating the financial management of a fairly large village in the future is one of the reasons for the formation of BUMDes. If it is not assisted by the establishment of a bumdes, the village may find it difficult to manage the funds it has. BUMDes is also a driving sector for new industries and accelerates the economic improvement of the people in the village. BUMDes are also involved in managing funds originating from the central government and from local governments so that they become more useful for economic development and the fulfillment of basic government services.

BUMDes is an entity in the form of a business entity, formed due to the ownership of separated village assets such as BUMN and BUMD. So that in the imposition of tax obligations for BUMDes it is treated as corporate tax. The tax must meet two elements of the tax, namely the subject of corporate tax and the object of corporate tax (Kurnia, 2015). The subject of corporate tax is a combination of people and/or capital which is a unit, resulting from doing business or not, which includes, BUMDes, BUMN, BUMD, Limited Liability Companies, Limited Liability Companies and others. Meanwhile, the object of tax is any additional economic income obtained or received by the entity, both originating from Indonesia and outside Indonesia, which is used for consumption or from the agency, in whatever name and form (Mardiasmo, 2016).

For village government tax obligations, the imposition is only related to $\mathrm{PPh} 21, \mathrm{PPh} 22$, PPh23, PPh article 4 paragraph 2 and PPN (if it has been determined to be a VAT Taxable Entrepreneur). The tax collector is the Bumdes treasurer. Bumdes is not a tax collector on APBDes funds, the tax collector is the duty of the village treasurer (Nordiawan, et al, 2009). 
The maturity date for reporting Annual Notification Letters for BUMDes is a maximum of April 30 of the following year.

Village Owned Enterprises (BUMDes) are business entities whose capital is either wholly or most of the village through participation, either directly or indirectly from village assets. The ownership is separated to manage assets, services from services, and other businesses, which are used as much as possible for the welfare of the community.

So far, we know that government programs are not taxed. However, if we better understand the explanation of the tax object, we can interpret it as a transaction (usually sourced from income) which, according to tax regulations, is classified as a transaction that must be taxed. Income from a foundation that comes from donations or grants is not a tax object. BUMDes has operational activities where from these activities it can generate profits, so, from this explanation, BUMDes have met a requirement as a tax object.

The Faculty of Economics and Business has been accompanying the Bambu Cisaat Village Tourism Village, Banyuresmi, Pandegelang. The Tourism Village also has a Joint Village BUM, which is a combination of several Bumdes around the Tourism Village who collaborate to promote this pioneering Tourism Village. The BUM Desa Bersama Mina Agro Tourism was established through the Inter-Village Mustawarah (MAD) which was attended by village heads, BPD Heads, Community Leaders, Youth, Entrepreneurship and other village delegates, as well as an invitation from the Village Council and Village Representatives. Regions and RepresentativesKec. Labuan and Jiput. Produced: Regulations with the Labuan Village Head, Teluk Village Head, Caringin Village Head, Banyubiru Village Head, Jiput Village Head, Banyuresmi Village Head, Banyuresmi Village Head, Sukacai Village Head and Tenjohalang Village Head Number 011 of 2018, Number 007 of 2018, Number 08 of 2018, Number 002 of 2018, Number 03 of 2018, Number 03 of 2018, Number 010 of 2018, and Number 02 of 2018, Number 003 of 2018. Regarding cooperation between villages, the establishment of a Village Owned Enterprise with MINA AGRO WISATA and the establishment of a Village Owned Enterprise with MINAAGRO WISATA.

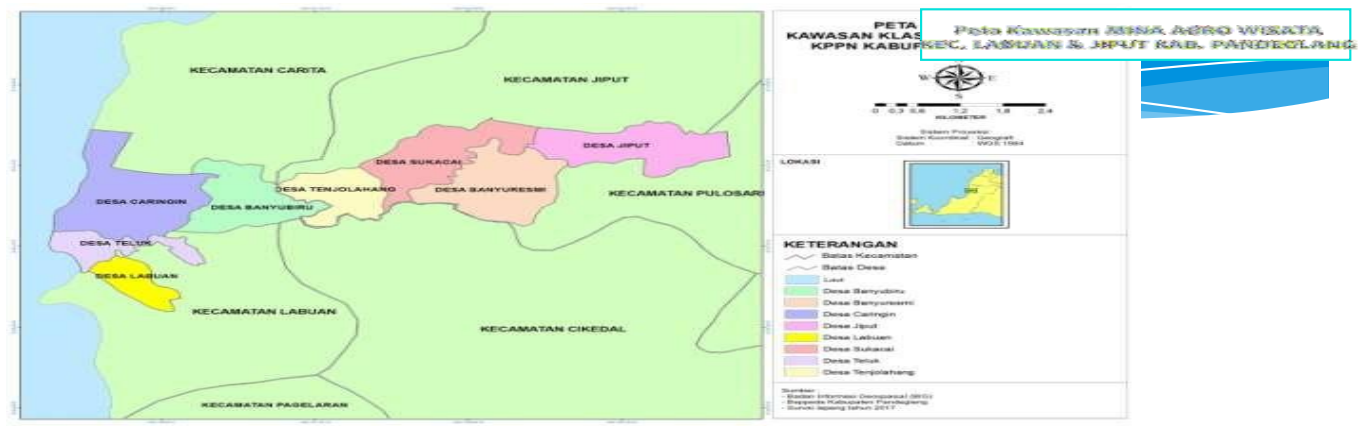

Figure 1. Map of Location of the Second Region of Partners 
Table 1. Problems and solutions for partners

\begin{tabular}{|c|c|c|}
\hline Partner & The Problem Partner & Solutions for Partners \\
\hline $\begin{array}{l}\text { BUM Desa } \\
\text { Bersama Mina } \\
\text { Agro Wisata }\end{array}$ & $\begin{array}{l}\text { 1. There is still a lack of tax knowledge } \\
\text { for the Village-Owned Enterprises } \\
\text { together } \\
\text { 2. BUM Desa does not understand self- } \\
\text { assessment both in calculating, } \\
\text { depositing and reporting taxes on their } \\
\text { income. }\end{array}$ & $\begin{array}{l}\text { 1. Education and Tax Assistance for } \\
\text { Bumdesa together } \\
\text { 2. Self-assessment training and } \\
\text { assistance in calculating, } \\
\text { depositing and reporting taxes on } \\
\text { their income. }\end{array}$ \\
\hline
\end{tabular}

The purpose of this service activity is to increase awareness and understanding of taxes for BUM Desa Bersama.

\section{METHOD}

Bumdesa which will be partners in this service is Bumdesa with MINA AGRO TOURISM. The stages of the method in this service are carried out as follows: the first is the socialization of the role of Bumdesa in development participation, so it is hoped that it can increase the awareness and knowledge of BUMdesa as its role as a taxpayer in state development through taxes, which is the first stage to be carried out. Furthermore, socialization of the self-assessment of taxpayers in taxation for Bumdesa with the aim of increasing understanding and awareness of the Bumdesa tax is the second stage to be carried out.

And the last method is, the practice is carried out by inviting the bumdesa to take steps to fulfill its tax obligations, and to find out whether the material provided has been conveyed to all bumdesa participants. In order for effective, two-way communication to occur between the presenters and participants, and so that the information conveyers do not get bored with the participants. The practice above is the third method that we do in this service. Practical activities in this third method begin with calculating taxation, depositing tax obligations and reporting tax obligations. The practical implementation begins with training and assisting the bumdes in tax calculations, tax payment procedures and tax reporting training. The summary of the implementation methods to be carried out in this activity are as follows:

Table 2. Implementation method to be used

\begin{tabular}{|c|c|c|}
\hline No. & \multicolumn{1}{|c|}{ Target } & \multicolumn{1}{c|}{ Methodology Implementation } \\
\hline 1. & $\begin{array}{c}\text { Building the mindset of BUM Desa } \\
\text { actors regarding its role in development } \\
\text { and the importance of taxes for Country }\end{array}$ & $\begin{array}{l}\text { Conduct socialization and education regarding the } \\
\text { role of BUmdesa in development, with the aim of } \\
\text { increasing awareness and knowledge of BUmdesa } \\
\text { service participants regarding the important role of taxes } \\
\text { for state development. }\end{array}$ \\
\hline 2. & $\begin{array}{c}\text { Training and mentoring for tax } \\
\text { calculation BUMDes business income }\end{array}$ & $\begin{array}{c}\text { Training and assistance in tax calculation is carried } \\
\text { out by directing bumdesa participants to calculate } \\
\text { directly the amount of tax owed. }\end{array}$ \\
\hline 3. & $\begin{array}{c}\text { Training and assistance for depositing } \\
\text { and reporting taxes for Village-owned bumdesa to take steps to fulfill their tax } \\
\text { Enterprises with an e-filling system }\end{array}$ & $\begin{array}{l}\text { invites bume } \\
\text { obligations, as well as to find out whether the material } \\
\text { provided has been conveyed to all bumdesa participants }\end{array}$ \\
\hline
\end{tabular}




\section{MAIN WORKS AND DISCUSSION}

Socialization regarding the role of BUM Desa Bersama in development is the beginning of this service activity, so it is hoped that it can increase awareness and knowledge of BUM Desa Bersama about its role as a taxpayer who indirectly participates in state development. In addition to increasing awareness of its role in development, this socialization activity is also expected to increase awareness of the joint bumdesa for tax payments and knowledge of the tax benefits obtained for the joint bumdesa.

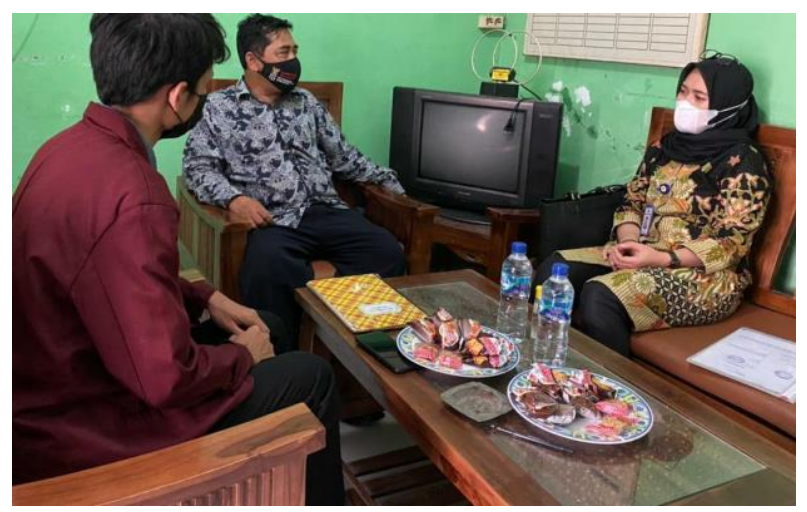

Figure 2. Socialization of the Role of BUM Desa Together for Development

The next stage after the socialization activities, the next stage, namely training activities and tax calculation assistance, is carried out by directing bumdesa participants to directly calculate the amount of tax owed. The implementation of training and assistance is carried out with the aim of helping BUM Desa Bersama actors who have problems in making TIN and have difficulties when reporting taxes or calculating taxes. The stages of this service activity are as follows: The material provided is done by presenting materials related to tax calculations, procedures for paying taxes in an easy way that can be done through ATMs, bank tellers, internet banking, mobile banking, e-mail, even the post office, as well as material presentations on the procedures for reporting BUM Desa Bersama tax.

When carrying out the activities there were no significant difficulties during the presentation of the material and discussions with the BUM Desa Bersama participants. The material provided by the resource persons relates to an explanation of tax inclusion, $\mathrm{PPh}$ article 21, article 22, article 23 and article 4 paragraph 2. The resource person describes the related materials: Tax Awareness/Tax Inclusion, Definition of subject and object of tax, Which does not include subject and object of tax which are not subject to Income Tax Articles 21, 22, and 23. Calculating taxes owed, Educational procedures and practices for the implementation of tax obligations, the procedure for registering a TIN and the requirements for registration, the procedure for calculating the amount of income tax from Bumdesa, Tax reporting procedures, procedures for payment of tax obligations. 

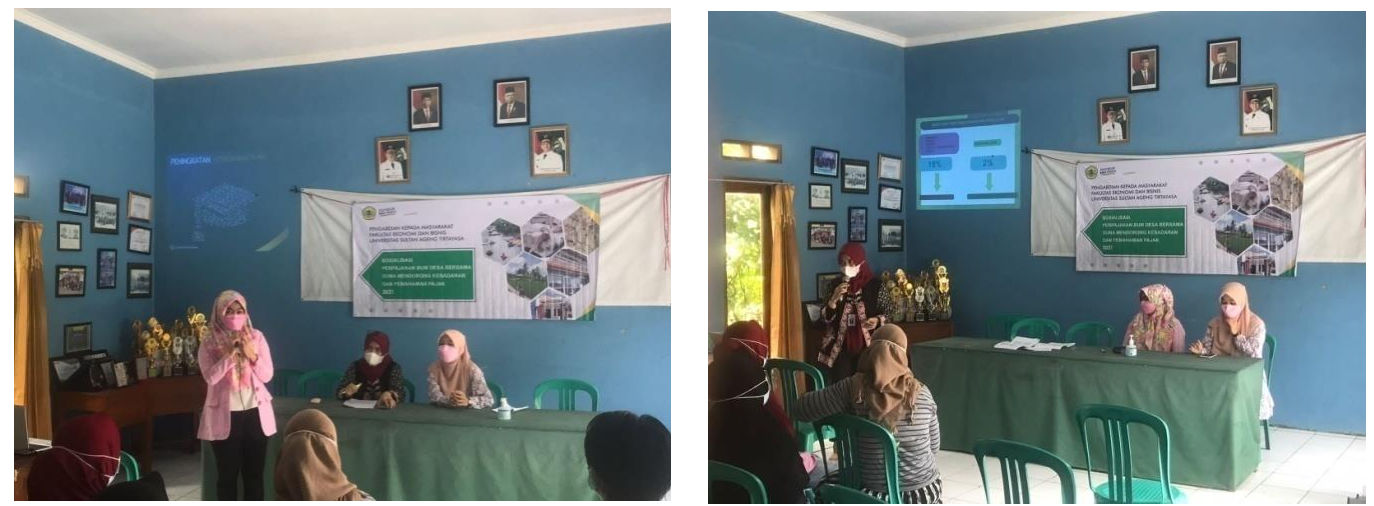

Figure 4. Provision of Tax Training Materials

In this training method service activity, the participants of BUM Desa Bersama are very enthusiastic, there are several BUM Desa who still do not understand related to taxation. There are important findings that we found in this community service activity for BUM Desa Bersama, namely: BUM Desa Bersama has not yet made complete financial records and there are still those who do not understand how to record financial statements.

Some BUM Desa that do not yet have an NPWP because they do not know how to make an NPWP due to the lack of information they have about what prerequisites are needed in making an NPWP. BUM Desa Bersama does not understand how to calculate how much tax liability is, report the tax, besides that the turnover they generate from their business is still very minimal.

This training activity and tax assistance are carried out to help BUM Desa Bersama understand every training material that has been provided. Assisting BUM Desa Bersama to understand how to calculate the amount of taxes, process tax payments to make reports for taxes owed.

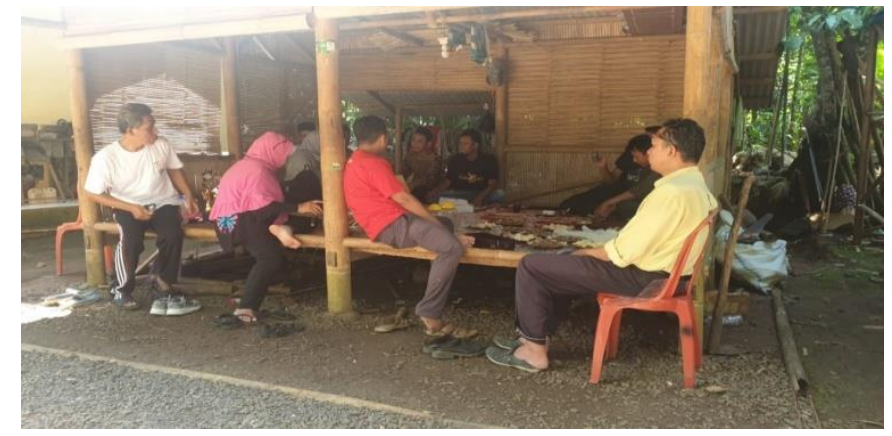

Figure 5. Training activities and assistance in tax calculation and reporting

Activities in service training are carried out by practicing calculating the amount of taxes from transactions that exist in the bumdesa, how to calculate the amount using pph 21,22 and 23 tariffs. The purpose of these activities is to determine the extent to which the 
materials and training received by each bumdester participant are related to the materials presented.
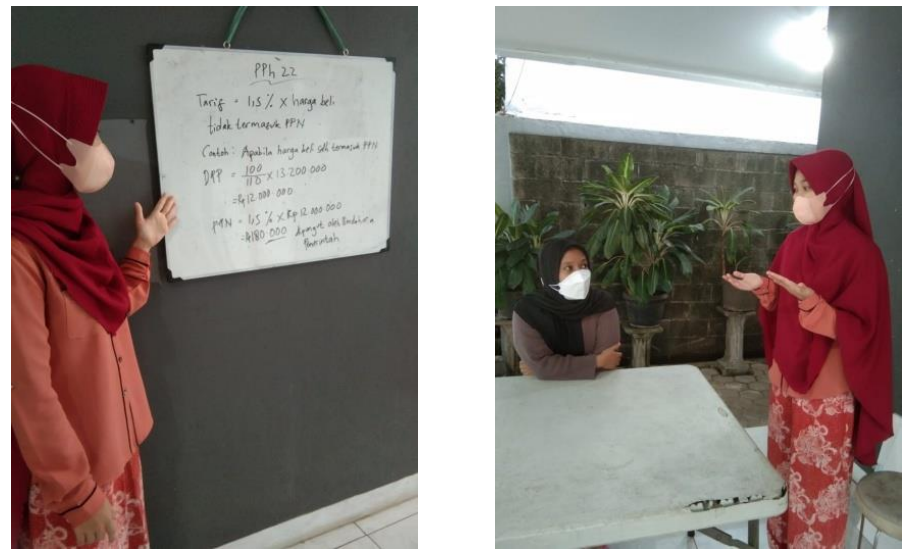

Figure 6. Photos of tax calculation and reporting assistance activities

\section{CONCLUSION}

This tax service activity has the aim of providing training and assistance for BUM Desa Bersama related to taxation, by providing an understanding of the basic concepts of taxation, self-assessment, which includes, how to calculate taxes owed, how to pay taxes owed and submit reports on their tax obligations. increase knowledge about the role of BUM Desa Bersama in development through taxes.

In addition, it increases the knowledge of BUM Desa Bersama regarding the manufacture and benefits of having a NPWP, and invites BUM Desa Bersama actors to fulfill their tax obligations, namely paying taxes, and participants understand the benefits of taxes. and the limited information they have regarding what are the prerequisites for making the TIN.

From this research, it was found that BUM Desa Bersama has not made a proper and complete recording of financial transactions and there are still some who still do not know how to do the recording for the preparation of its financial statements.

BUM Desa Bersama are still unsure about how to calculate taxes and report taxes because they do not understand and understand the procedures for calculating taxes and reporting taxes and the turnover of their business results is still very minimal so they have not reported BUM Desa Bersama taxes. Suggestions for further service is, in addition to tax service, it needs to be accompanied by good and easy material for making financial reports.

\section{THANK-YOU NOTE}

We would like to thank those who helped in the implementation of this service activity. First of all, we would like to thank the Faculty of Economics and Business, Sultan Ageng Tirtaysa University for supporting all needs and facilitating in various ways, so that this community service activity can run. In addition, I would also like to thank the Village-Owned Enterprises with MINAAGROWISATA for being willing to be partners in community service activities. 


\section{DAFTARPUSTAKA}

Agunggunanto, E. Y. 2016. Pengembangan Desa Mandiri Melalui Pengelolaan Badan UsahaMilikDesa (BUMDes). Jurnal DinamikaEkonomidan Bisnis, 67-81.

Agus Taufik Hidayah, A. T., Pujiati, L., Hidyati, N., Hendrawan, S. A., Suprapto, S., \& Ali, N. 2018. Pendampingan Penyusunan Laporan Keuangan Pada Badan Usaha Milik Desa(Bumdes) Lestari Desa Bandung Kecamatan Diwek Jombang. Journal of communityservice, 2, 15-20.

Anggraeni, M. R. 2016. Peranan Badan Usaha Milik Desa (BUMDes) Pada Kesejahteraan Masyarakat Pedesaan. Modus Journal, 28(2),155-167.

Ihsan, A. N. (2018). Analisis Pengelolaan Badan Usaha Milik Desa ( BUMDes ) Gerbang Lentera Sebagai Penggerak Desa Wisata Lerep. Journal of Politic and Governmen tStudies.7(11).

Kurnia,Dadang. 2015. Pengawalan Akuntabilitas Pengelolaan Keuangan Desa. BPKP. Jakarta.

Mardiasmo. 2009. Akuntansi Sektor Publik Jakarta: CVAndi Offset.

Mardiasmo. 2016. Perpajakan Edisi Terbaru Tahun 2016. Yogyakarta: Andi Offset.

Nordiawan,Deddi,Iswahyudi Sondi Putra, dan Maulidah Rahmawati. 2009 .Akuntansi Pemerintahan. Yogyakarta: SalembaEmpat.

Prabowo, T.H.E. 2014 . Developing BUMDes (Village-owned Enterprise) for Sustainable Poverty Alleviation Model Village Community Study in Bleberan-Gunung KidulIndonesia. World Applied Sciences Journal 30 (Innovation Challenges in Multidiciplinary Research \& Practice): 19-26.

Undang-Undang Republik Indonesia Nomor6 Tahun 2014 Tentang Desa. 